\title{
Huistijdschriften van Duitse theaters tijdens de Republiek van Weimar
}

\section{PAUL OP DE COUL}

Ruim anderhalf jaar geleden ging een internationaal en interdisciplinair onderzoeksproject van start onder de titel 'Musiktheater in Deutschland I900-1950'. Aan dit project, dat een gezamenlijk initiatief is van de afdeling Muziekwetenschap van de Universiteit Utrecht, het Forschungsinstitut für Musiktheater van de Universität Bayreuth en het Institut für Theaterwissenschaft van de Universität München, wordt deelgenomen door ongeveer vijfentwintig onderzoekers: musicologen, theater-, dans- en filmwetenschappers, en cultuur- en kunsthistorici uit verschillende Europese landen en de Verenigde Staten. ${ }^{\mathrm{I}}$

Doel van de onderneming is de voorbereiding van een in methodologisch opzicht nieuwe geschiedenis van het muziektheater (opera, operette, dans, revue) in Duitsland in de eerste helft van de twintigste eeuw. In aansluiting op het project, dat een looptijd heeft van drie jaar, is een meerdelige publicatie gepland. In tegenstelling tot de traditionele historiografie van het muziektheater, die zich vrijwel geheel beperkt tot werk- en genre-aspecten, richt het project zich op hetgehele muziektheatrale systeem in zijn contextuele verankering. Dit komt enerzijds tot uiting in een verbreding van het onderzoeksterrein doordat behalve compositie ook infrastructuur, productie (in de betekenis van theaterproductie), receptie, en distributie door toen nieuwe media als grammofoonplaat, radio en film bijzondere aandacht zullen krijgen. Anderzijds is er sprake van een verdieping doordat de wisselwerking tussen de verschillende deelgebieden van het muziektheatrale systeem alsmede de invloed op dat systeem van politieke, sociale en culturele ontwikkelingen, ook bij het onderzoek zullen worden betrokken.

Vanaf de vroege decennia van de twintigste eeuw vonden op alle terreinen van het muziektheater fundamentele veranderingen plaats. Dit proces manifesteerde zich niet alleen in een grote verscheidenheid aan nieuwe vormen van muziektheater, maar evenzeer in de cultuurpolitieke context, in de enscenering en in de receptie door een publiek dat uit zeer verschillende sociale lagen was samengesteld. Technische verworvenheden van de late negentiende eeuw, zoals de toepassing van het elektrische licht in het theater, en een door de natuurwetenschap veroorzaakt nieuw besef van tijd en ruimte, waren van verstrekkende betekenis voor de ontwikkeling van de ensceneringspraktijk. Een nieuwe visie op de mens op het toneel, onder meer ontwikkeld onder invloed van de Wandervogel- en Jugendbewegung en vooral van de ritmische gymnastiek (Emile Jaques-Dalcroze) en de Ausdruckstanz of vrije dans (Rudolf von Laban, Mary Wigman), vonden hun neerslag in volstrekt andere ensceneringsvormen. Een parallelle ontwikkeling was het ontstaan van professionele organisaties van het theaterpersoneel en van publieksverenigingen van verschillende politieke of levensbeschouwelijke signatuur. Door de emancipatie van de operaregie werd het 

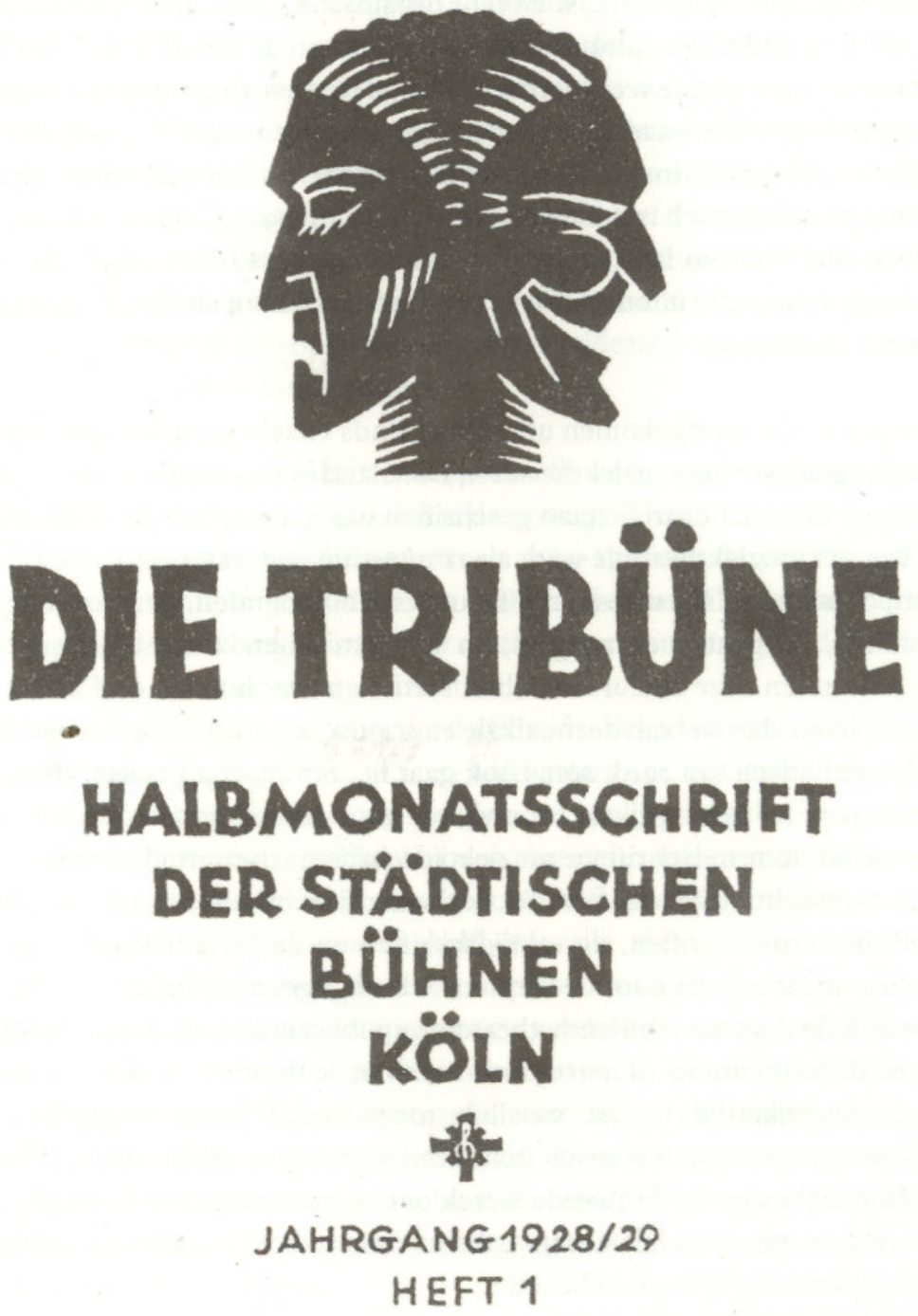
werkbegrip verruimd van compositie tot theaterkunstwerk. Nieuwe theatervormen, van kameropera tot massaregie, resulteerden in uitbreiding van de theaterscène tot buiten de officiële theaters. De integratie van technische media in het arsenaal van scenische uitdrukkingsmiddelen en de door grammofoon, radio en film verbrede receptie van het muziektheater zijn kenmerkend voor de periode waarop het project zich richt. Aan het begin van de jaren dertig en vooral na de machtsovername van de nationaal-socialisten valt een duidelijke teruggang van het experiment op alle terreinen van de kunst waar te nemen. Hoewel de organisatievorm van de theaters dezelfde bleef, vonden er onder het cultuurpolitieke regime van de Reichsmusik- en Reichstheaterkammer ingrijpende veranderingen plaats. De naoorlogse periode wordt algemeen gezien als een fase waarin een nieuw begin wordt gemaakt. Bij nadere beschouwing blijkt de personele, institutionele en esthetische continuïteit echter zo sterk te zijn, dat het problematisch is om de historische cesuur 1945 de grens van het project te laten bepalen. Daarom is er voor gekozen om die grens in het begin van de jaren vijftig te leggen, toen de cultuurpolitieke contouren van DDR en Bondsrepubliek zich begonnen af te tekenen.

Het project is mede voortgekomen uit mijn al sinds enkele jaren lopende onderzoek naar opvattingen over het muziektheater in Duitsland in de periode tussen omstreeks I900 en 1933. Centraal daarbij staan geschriften van al diegenen die bij de totstandkoming van het muziektheatrale werk als compositie en theaterproductie betrokken zijn: componisten en librettisten, regisseurs en choreografen, decorontwerpers en toneeltechnici, dirigenten en zangers, en tenslotte intendanten of theaterleiders. Dikwijls reflecteren deze auteurs over hun métier en over hun aandeel in het proces van de compositie dan wel van de muzikale en scenische realisatie, soms zijn hun teksten programmatisch van aard, soms ook gaat het om meer algemeen theoretische beschouwingen. De belangrijkste bron van de voor dit onderzoek relevante teksten wordt gevormd door tijdschriften: muziektijdschriften, theatertijdschriften en algemene kunst- en cultuurtijdschriften. Tot de theatertijdschriften behoren niet alleen de algemene theatertijdschriften, de vaktijdschriften en de periodieken van publieksorganisaties, maar ook de door de theaters zelf uitgegeven tijdschriften. Een aparte categorie zijn de door verschillende theaters gepubliceerde jaarboeken en almanakken. Vooral de programma- of huistijdschriften van de theaters vormen een bijzonder rijk, maar tegelijkertijd uiterst moeilijk toegankelijk bronnenmateriaal. Huistijdschriften zijn nooit systematisch door bibliotheken gecollectioneerd; bovendien zijn veel Duitse theaters in de Tweede Wereldoorlog gebombardeerd, waarbij hun archieven verloren zijn gegaan. Slechts enkele bibliotheken bezitten een substantiële verzameling van dergelijke periodieken. ${ }^{2}$

Maar er zijn altijd lacunes en daarom is het dikwijls nodig om de in verschillende bibliotheken aanwezige onvolledige bestanden van een tijdschrift bij wijze van spreken samen te voegen om een jaargang of een jaargangenreeks compleet te maken. Een ernstige handicap is ook het ontbreken van gedegen bibliografische publicaties met betrekking tot theatertijdschriften: de meest recente bibliografieën dateren uit de jaren twintig van de vorige eeuw. ${ }^{3}$

Voor I9I8 waren er maar enkele theaters die een huistijdschrift uitgaven. Pioniers waren het Schiller-Theater in Berlijn (Zwanglose Hefte für die Besucher des Schiller-Theaters, sinds I894), het Schauspielhaus in Düsseldorf (Masken, sinds I905), het Stadttheater 
in Düsseldorf (Düsseldorfer Stadttheater, sinds I909) en het Deutsches Theater in Berlijn (Blätter des Deutschen Theaters, sinds I9II). Behalve het Stadttheater in Düsseldorf ging het om theaters die uitsluitend toneelvoorstellingen gaven; en met uitzondering van datzelfde Stadttheater waren het nieuw gevestigde, particuliere theaters, die alle een bijzondere reden hadden om contact met het publiek te zoeken via het publicitaire middel van een eigen orgaan. Het Schiller-Theater was een volkstheater en richtte zich op een middenstandspubliek dat weinig of niet met het toneel vertrouwd was; het door Louise Dumont en Gustav Lindemann gestichte Schauspielhaus in Düsseldorf had daarentegen grote artistieke idealen, was uitgesproken modernistisch en wilde bovendien een regionaal centrum van cultuur zijn; voor de eigenaar van het Deutsches Theater in Berlijn, Max Reinhardt, vormde het theatrale aspect (en niet het levensbeschouwelijke, ethische of literaire) de essentie van het theater, en die visie moest ook het huistijdschrift helpen uitdragen. Het Stadttheater in Düsseldorf ten slotte was een van de eerste door de stedelijke overheid gefinancierde theaters die een programmaperiodiek uitbrachten. Maar dat had waarschijnlijk minder te maken met artistieke doelstellingen of culturele vormingsidealen dan met de nabijheid van het theater van Dumont en Lindemann. ${ }^{4}$

Na de Eerste Wereldoorlog maakten huistijdschriften een opmerkelijk bloei door. Dat proces begon in de jaren rond 1920, maar de grote golf van nieuwe huisperiodieken kwam met het begin van het theaterseizoen $1924-25$, toen de periode van inflatie voorbij was en het economisch herstel van de Republiek van Weimar inzette. Voor een goed begrip van deze ontwikkeling is het nodig, een moment de aandacht te richten op de instellingen die ze uitgaven, de theaters.

Het Duitse theaterlandschap is in zijn dichtheid uniek in Europa. Tot het einde van de Eerste Wereldoorlog waren er zo'n 20 hoftheaters en 200 stadstheaters. Bij ongeveer driekwart van de laatste categorie ging het om theatergebouwen die door de stedelijke overheid waren verpacht aan een directeur. De overige theaters waren grotendeels is particuliere handen; in slechts enkele gevallen drukten zij op de gemeentelijke begroting. Ongeveer de helft van alle theaters waren zogenaamde "Mehrspartentheater", theaters die zowel opera- en operette- als toneelvoorstellingen gaven (en als het om grotere theaters ging ook balletuitvoeringen). Gedurende het theaterseizoen werd in principe elke avond gespeeld. Daarbij hanteerde men het repertoire-systeem: er werd een keuze gedaan uit een aantal ingestudeerde werken (het repertoire) en daarnaast konden elk seizoen enkele premières worden uitgebracht. Die nieuwe werken werden dan aan het repertoire toegevoegd, zodat ensceneringen die al jaren lang meegingen en tekenen van slijtage begonnen te vertonen, ervan konden worden afgevoerd.

$\mathrm{Na}$ de revolutie van I9I8-I9I9, die een eind maakte aan het Wilhelminische keizerrijk, kwamen de meeste hoftheaters onder beheer van de deelstaten. Slechts enkele - de hoftheaters in Berlijn, Kassel en Wiesbaden - kwamen op de begroting te staan van het ministerie van cultuur van de nieuwe democratische republiek. De stadstheaters werden in gemeentelijk beheer genomen. Door deze ontwikkeling ontstond een volstrekt nieuwe situatie: niet meer de landsheren of de keizer waren verantwoordelijk voor de financiering van de theaters, maar de bevolking, de belastingbetaler. Geen wonder dat de theaters zich veel meer dan voorheen gingen inspannen om de interesse van die belastingbetaler te wekken. Die inspanning werd overigens ook gemotiveerd door het feit dat de theaters het als hun opdracht 
beschouwden om een actieve rol te spelen in het maatschappelijk-culturele veranderingsproces van na de Eerste Wereldoorlog. Daaruit vloeide de verplichting voort, zich te bewijzen als een subsidiabel onderdeel, ja zelfs als centrum van het stedelijke en nationale culturele leven. ${ }^{5}$

Tegen die achtergrond wordt de regelrechte boom van huistijdschriften in de periode na de Eerste Wereldoorlog begrijpelijk. Want het was een belangrijke taak van huisorganen om het contact met het publiek tot stand te brengen en te onderhouden. Daarnaast konden zij door de plaatsing van advertenties een aangename bron van neveninkomsten zijn. Wat het aantal pagina's betreft dat hieraan werd besteed, maakten enkele bladen het wel erg bont: in het blad Die Oper van het stadtstheater in Breslau bijvoorbeeld zijn soms wel 25 achtereenvolgende pagina's gevuld met uitsluitend advertenties!

Dat het contact met het publiek hoog op de agenda stond, komt dikwijls goed tot uiting in programmatische verklaringen van de redacteur - doorgaans de dramaturg of van de intendant van het theater bij de start van een nieuw huisorgaan. Zo opent het eerste nummer van de Blätter der Staatsoper in Berlijn (3I oktober 1920) met een redactioneel 'ten geleide' waarin de motieven worden genoemd om een eigen tijdschrift in het leven te roepen: ten eerste het streven om bij de opvoering van onbekende en moeilijk toegankelijke werken het publiek vertrouwd te maken met de bedoelingen van componist en librettist, en het een handreiking te bieden voor een beter begrip van het werk en de wijze waarop het wordt geënsceneerd; vervolgens de behoefte om verantwoording af te leggen over het werk van de Staatsoper alsook over het toekomstige artistieke beleid en daarnaast het publiek enig inzicht te geven in het complexe ontstaansproces van een operaproductie; en ten lotte de wens om belangwekkende, niet eerder gepubliceerde muziekhistorische documenten uit het rijke archief van de opera openbaar te maken. Aan het begin van de tweede jaargang (september 192I) wordt vastgesteld dat het punt van de verantwoording over het werk en het artistieke beleid nog te weinig uit de verf is gekomen. In de komende nummers, zo wordt aangekondigd, zullen daarom regelmatig bijdragen verschijnen van de hand van de artistieke staf van het bedrijf, dus van de chef-dirigent, de regisseur en de decorontwerper. En om te bevorderen dat het blad door meer operabezoekers wordt gelezen, zal het bij elke première en nieuw ingestudeerde reprise gratis aan het publiek van de eerste avond worden uitgedeeld.

Het eerste nummer van de Blätter der Städtischen Bühnen in Frankfurt (juli 1924) wordt ingeleid met een beginselverklaring van Richard Weichert, intendant van het Schauspielhaus. Zijn betoog kan als volgt worden samengevat. Het theater is een spiegel van onze tijd, van onze huidige cultuur. Wij staan voor een failliet Europa en beleven het bankroet van een wereldoorlog. Duitsland heeft zijn theaters in stand weten te houden, ondanks oorlog, revolutie en inflatie. Maar nu, in een fase van opbouw, dreigt er een nieuw gevaar: de onderschatting van de betekenis en waarde van het theater. Men denkt het te kunnen afdoen als een plaats van amusement en aangename verstrooiing. Tegen die mentaliteit willen wij in dit tijdschrift strijden, omdat we geloven in de kracht van het theater als kunstinstelling. Vanuit dat geloof werken we en willen we voor ons werk een klankbord vinden bij degenen die voor ons onmisbaar zijn, namelijk het publiek. We hebben het publiek nodig, want pas de drie-eenheid van auteur, acteur en publiek is schepper van het theatrale kunstwerk. Over de auteur en over degenen die het theatrale kunstwerk doen ontstaan, zal op deze plek niet ge- 


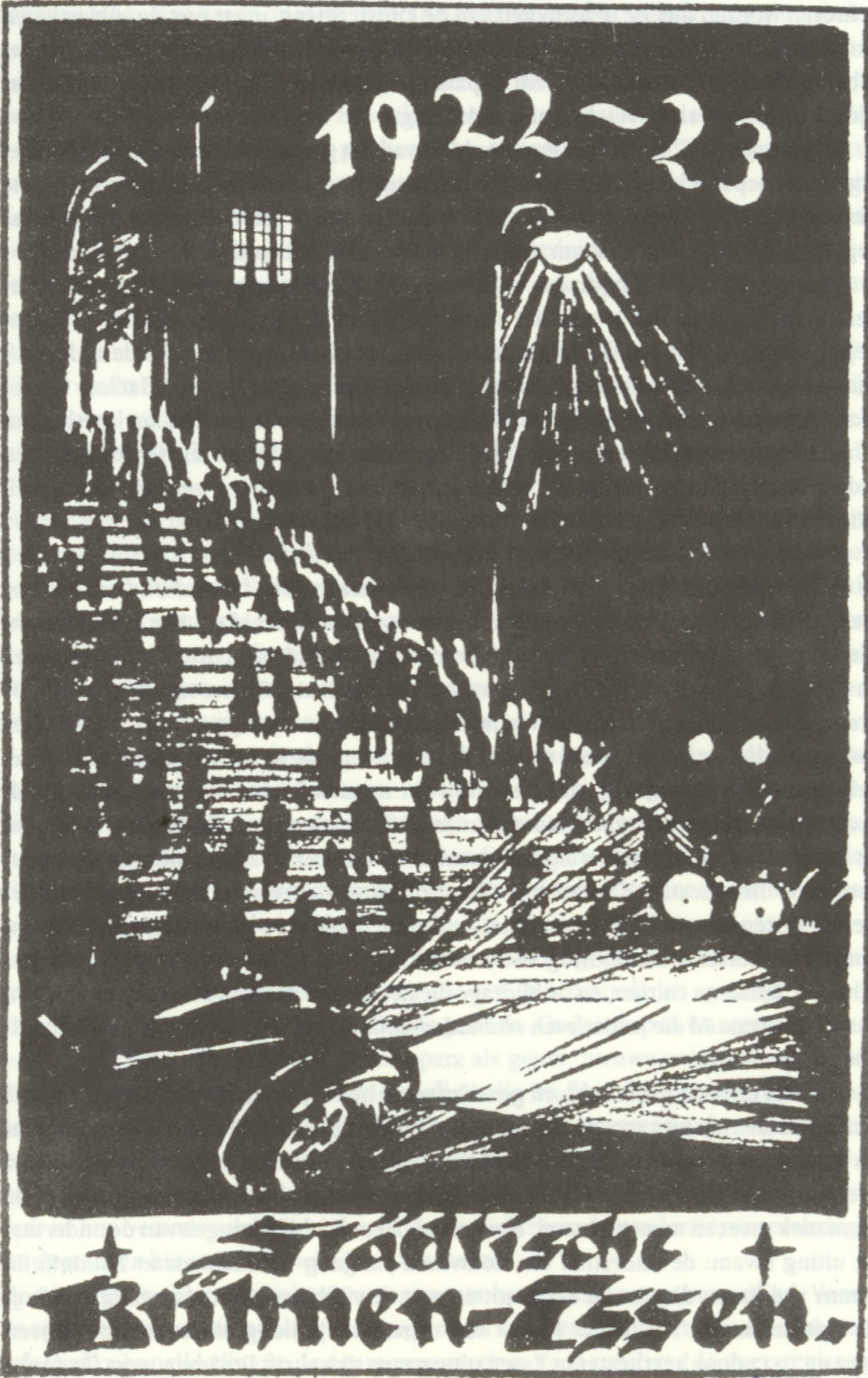

Omslag (ontwerp: Hermann Härtlein) van het Jahrbuch 1922-23 van de Städtische Bühnen in Essen 
schreven worden met de objectiviteit van de kunstcriticus, maar met de subjectiviteit van de creatieve kunstenaar: verklarend vanuit eigen ervaring, polemisch, en als het moet agressief. "Die instelling zal bepalend zijn voor het gezicht van ons theatertijdschrift", zo besluit Weichert zijn verklaring.

De veronderstelling dat het lezerspubliek van het gemiddelde huistijdschrift in het algemeen beperkt bleef tot de theaterbezoekers van stad en regio, mag op het eerste gezicht plausibel lijken, maar juist is zij niet. Ten eerste verschenen sommige huisorganen als bijlage bij een krant, zoals bijvoorbeeld in Baden-Baden en Mannheim. ${ }^{6}$

Ten tweede werden bijdragen vaak door tijdschriften van andere theaters overgenomen. En tenslotte kwam het regelmatig voor dat artikelen opnieuw werden gepubliceerd in de Musikblätter des Anbruch, het internationaal verspreide tijdschrift van de Weense muziekuitgever Universal Edition. Paul Stefan, hoofdredacteur van dit blad - een van de belangrijkste tijdschriften voor moderne muziek in het interbellum - had het opnieuw publiceren van in zijn ogen belangwekkende teksten zelfs tot een redactioneel principe verheven, onder het motto: "Wichtiges gewinnt nur durch Wiederholung". ${ }^{7}$

Er zijn ruwweg drie typen huisperiodieken te onderscheiden. ${ }^{8}$ De inhoud van het eerste type wordt bepaald door de in het theater opgevoerde stukken. Het is in feite niet meer dan een programmablad, en bevat voornamelijk bijdragen over auteur (bij opera en operette: componist en librettist), stuk en enscenering. Bij het tweede type zijn de grenzen wat ruimer getrokken en kunnen ook artikelen zijn opgenomen over onderwerpen als het artistieke beleid van het theater, het publiek, actuele tendensen op het gebied van de enscenering, theorieën van het muziektheater, theaterkritiek, of cultuurpolitiek. Het derde type tenslotte emancipee zich nog verder van het speelplan en heeft het karakter van een algemeen cultureel tijdschrift, zij het met een bijzonder accent op het theater. Theater-huistijdschriften van de eerste twee typen zijn het sterkst vertegenwoordigd. Het relatief zeldzame derde type kwam vooral in de jaren kort na de Eerste Wereldoorlog voor, toen het geloof in de vernieuwing van maatschappij, kunst en cultuur, en de bijdrage die het theater daaraan zou kunnen leveren, het sterkst was. Al die initiatieven strandden door de inflatie, die in 1923 een recordhoogte bereikte.

Een van de belangrijkste breed georiënteerde huistijdschriften van voor de inflatie was het tussen I9I7 en I92I in Dresden gepubliceerde blad Der Zwinger. Opgericht met als ondertitel Blätter der Dresdner Hoftheater, beperkte het zich aanvankelijk tot het speelplan en algemene aspecten van het theater. In de volgende jaargangen werd de thematiek meer en meer verbreed, een proces dat ook in wijzigingen van de ondertitel tot uiting kwam: de ondertitel van de tweede jaargang luidde Dresdner Zeitschrift für Theater und Kunst, die van de derde tot en met de vijfde en laatste jaargang Zeitschrift furr Weltanschauung, Theater und Kunst. ${ }^{9}$ Van uitzonderlijk hoog niveau was het tussen I927 en 1933 door het theater in Essen uitgegeven tijdschrift Der Scheinwerfer. Ondanks de ondertitel Blätter der Städtischen Bühnen Essen was dit blad veel méér dan een programmatijdschrift van een provinciaal stadstheater in het Ruhrgebied. In het nawoord bij de in 1985 verschenen editie van een geselecteerd aantal teksten uit dit tijdschrift wordt er op gewezen dat het blad zich juist op grond van de provinciale situatie waarin het werd geconcipieerd, tot een forum voor kunst en cultuur ontwikkelde van meer dan regionale betekenis. ${ }^{\text {to }}$

Redacteur Hannes Küpper, dramaturg van de twee stadstheaters (Opernhaus en 
Schauspielhaus) in Essen, maakte Der Scheinwerfer tot een discussieforum voor meningen, programma's en controverses met betrekking tot een aantal wezenlijke artistieke, culturele en politieke tendensen van die tijd. Tot de auteurs die in Der Scheinwerfer over kwesties op het gebied van muziek, opera, toneel, dans, literatuur, film, radio, beeldende kunst en architectuur publiceerden, behoren Theodor W. Adorno, Bertolt Brecht, Elisabeth Hauptmann, Kurt Jooss, Ernst Krenek, Heinrich Mann, Josef Roth, Kurt Weill en Arnold Zweig. Maar ook vertegenwoordigd zijn woordvoerders van de door historici als 'conservatieve revolutie' aangeduide intellectuele oppositiebeweging tegen de Republiek van Weimar, zoals de schrijver Ernst Jünger en de journalist Richard Bie.

Met hun rijk geschakeerde inhoudelijke spectrum vormen tijdschriften als Der Zwinger en Der Scheinwerfer interessante, maar - omdat ze relatief moeilijk toegankelijk zijn - nog te weinig bekende bronnen voor het onderzoek naar aspecten van de Duitse cultuurgeschiedenis van na de Eerste Wereldoorlog.

In het kader van het onderzoek naar opvattingen over het muziektheater in Duitsland van rond 1900 tot 1933 heb ik een groot aantal periodieken op relevante bijdragen gescreend: huistijdschriften van een kleine vijftig theaters, jaarboeken en almanakken van vijfentwintig theaters, en daarnaast nog ongeveer zestig muziektijdschriften, theatertijdschriften en algemene kunst- en cultuurtijdschriften. Dat leverde enkele duizenden bijdragen op over toen actuele vraagstukken met betrekking tot de compositie en de productie van opera, operette, revue en danstheater. ${ }^{\text {II }}$

Van deze geschriften is slechts een klein percentage bekend, en dan gaat het vooral om teksten van componisten. Maar ook in deze categorie valt er nog veel nieuws te ontdelsken. Aan de geschriften van de theaterleiders en van de makers van de theaterproductie, de regisseurs, choreografen, decorontwerpers, toneeltechnici, dirigenten en zangers, is door de muziek- en theaterwetenschap tot nu toe echter nog nauwelijks enige aandacht besteed. ${ }^{\text {I2 }}$

Desalniettemin vormen juist deze teksten een belangrijke bron voor onze kennis van de theorie (in een ruime betekenis van het woord) en praktijk van de muziektheaterproductie in de betreffende periode. Onderwerpen waarover frequent werd geschreven zijn de toekomst van opera als genre, nieuwe vormen van muziektheater, opera/operette en de nieuwe media radio en film, het operalibretto en het probleem van de librettovertaling, ${ }^{{ }^{13}}$ de theorie van de operaregie, het onderscheid tussen toneel- en operaregie, de vrijheid van regisseur en decorontwerper ten aanzien van de ensceneringsaanwijzingen in de partituur, de relatie tussen dirigent en regisseur in hun verantwoordelijkheid voor de muziektheatrale productie, ensceneringsconcepten, en het artistieke beleid van het theater.

Als auteurs zijn componisten en regisseurs het sterkst vertegenwoordigd. Vooral na I9I8 nam het aantal publicerende regisseurs sterk toe. Dit heeft te maken met een belangrijke ontwikkeling in de opera-enscenering. Vóór Igoo was de operạregisseur niet veel meer dan een coördinator van het scenische gebeuren en had hij geen noemenswaardige artistieke inbreng; na de eeuwwisseling en vooral na de Eerste Wereldoorlog trad hij uit de anonimiteit en begon steeds duidelijker zijn stempel op de opera-enscenering te drukken. Hij werd een tegenhanger van de dirigent. De publicatielust van de operaregisseur getuigt van een groeiend zelfbewustzijn en een toenemende invloed op het productieproces van het muziektheatrale kunstwerk. 
Van de tijdschriften die in het onderzoek centraal staan, namen er enkele regelmatig het initiatief om vertegenwoordigers uit de wereld van de muziek en het theater naar hun mening over omstreden kwesties te vragen en hun reacties te publiceren. Hoewel enquêtes nu niet altijd de meest doorwrochte teksten plegen op te leveren, zijn zij van groot belang omdat zij inzicht kunnen geven in de verschillende opinies over onderwerpen die op een bepaald moment actueel zijn. In het hiernavolgende wordt aan twee van deze enquêtes kort aandacht besteed.

In 1928 wijdde het tijdschrift Die Scene een themanummer aan de publicatie van de ingezonden reacties op de enquête 'Kapellmeister und Opernregie'. ${ }^{14}$ De vraag, wie bij de totstandkoming van een operaproductie de artistieke leiding en eindverantwoordelijkheid moet hebben, de dirigent dan wel de regisseur, was al sinds het begin van de emancipatie van de operaregie regelmatig aan de orde gesteld. In 1903 pleitte de theatercriticus (en latere intendant en regisseur) Carl Hagemann ervoor, de algehele leiding ò bij een muzikaal begaafde regisseur te leggen of bij een dirigent met dramaturgisch inzicht en praktische theaterervaring. Uitgaande van de stelling dat er voor een opera maar één regieboek bestaat, namelijk de partituur, heeft de tweede optie duidelijk zijn voorkeur. Felix Mottl in München en Gustav Mahler in Wenen zijn voor hem de lichtende voorbeelden van een eenheid van dirigent en regisseur. In de jaren daarna is de discussie met name in Die Scene goed te volgen, vanaf de eerste jaargang in IgII tot in de late jaren twintig. De genoemde enquête van I 928 leverde niet minder dan dertig reacties op. Onder de respondenten bevonden zich vooral regisseurs, maar ook dirigenten en componisten. De overgrote meerderheid verklaarde zich, vanuit principiële of praktische overwegingen, tegen de personele unie van dirigent en regisseur. Dit standpunt kwam overigens overeen met de meest gangbare praktijk, namelijk dat dirigent en regisseur hun verantwoordelijkheid deelden en de regisserende dirigent een uitzondering vormde. Dat de spanning die een tweehoofdige leiding met zich meebrengt juist vruchtbaar kan zijn, werd onderstreept door regisseur Hans Esdras Mutzenbecher:
Die grundlegende szenische Vision wird fast stets von Regisseur und Bühnenbildner ihren Ausgang nehmen müssen. In dem dann über dem Fortgang der Arbeit einsetzenden, sachlichen, labilen Spannungsverhältnis zwischen Kapellmeister und Regisseur sehe ich ein durchaus positiv zu wertendes Element, das ohne Takt und mit persönlichem Ehrgeiz behandelt in die unleidliche Sphäre des Nebeneinanders münden wird, das aber - richtig verstanden - jene Kollektivarbeit erzeugt, in der die Urheber unwichtig, das Werk allein von Bedeutung ist. ${ }^{15}$

De enquête in Die Scene is overigens als sluitstuk van de discussie te beschouwen, want in latere jaren werd het thema hoogstens nog incidenteel aan de orde gesteld.

In oktober I927 werd in de Städtische Oper in Berlijn de opera Jonny spielt auf opgevoerd, waarmee de toen zevenentwintigjarige Ernst Krenek in vele Duitse theaters furore maakte. Dit werk, dat in februari van datzelfde jaar met overweldigend succes in Leipzig in première was gegaan, was het eerste voorbeeld van wat al snel 'Zeitoper' werd genoemd, een operagenre dat uitdrukking wilde zijn van het moderne leven en van het tijdperk van de techniek. De 'Zeitoper' gaat de uitdaging aan van de nieuwe media en kunstvormen die een enorme aantrekkingskracht op het grote publiek 


\section{Wie neugeboren}

fühlt man sich nach einem Bade mit den von tousenden Arzten bei Nervosifät empfohlenen
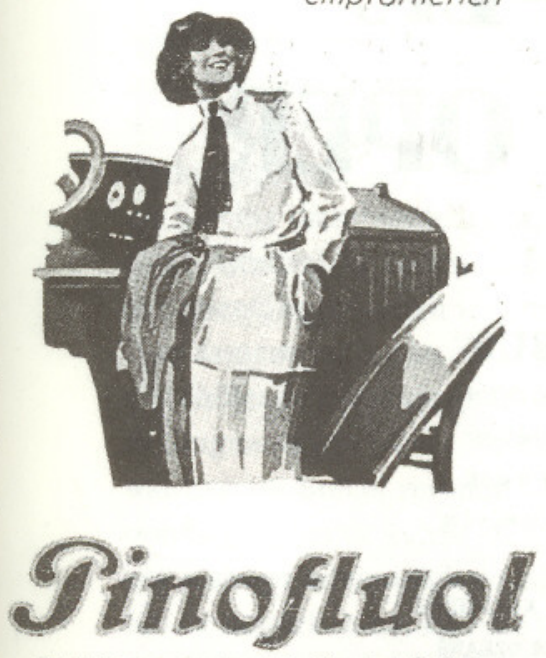

Fichtennadel-Kräufer-Bäder in Tabletten

Erhaltlich in allen Apotheken, Drogerien. parfïmerien

\section{Nur echt in dergrünen Packung}

Nochahmungen, die als ebensogut bezeichnet werden, weise man zurïck

In Blecholosen

Mehrfoch verstärkte Qualifät!

o BöderMk.3.so

12 Bd̃derMk.6.so

Wer die, Pinofluot-Bäderhochnicht kenntverlange umsonst Proben u BroschüreNo28

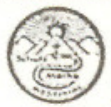

Westphal\&Sohn, Chem.Fobrik, FrankfurfaM. Aharmazeutisone Atreilung

Advertentie voor dennennaalden-en kruidenbaden in de Blätter der Städtischen Bühnen in Frankfurt a.M., 1929 uitoefenen, zoals de film, de radio, de revue en de populaire Amerikaanse dansmuziek. De titelheld van Jonny spielt auf is neger en violist van een jazzband, de handeling speelt zich onder meer af in een Parijs hotel en op een perron van een station (waar de trein naar Amsterdam klaar staat voor vertrek), shimmy, blues en tango drukken hun stempel op de muziek.

De redactie van de Blätter der Staatsoper und der Städtischen Oper had de opvoering van Kreneks opera aangegrepen om een vijftiental componisten de vraag voor te leggen: 'Wie denken Sie über die zeitgemässe Weiterentwicklung der Oper?' Hun antwoorden werden gepubliceerd in het ter gelegenheid van de opvoering van Kreneks opera verschijnende nummer van het tijdschrift. ${ }^{16}$

De enquête past geheel in de context van de toen bijzonder levendige debatten over nieuwe uitgangspunten en ontwikkelingsmogelijkheden van de opera. In de inleiding refereert de redactie aan de veelvuldig gehoorde mening dat de opera uit de tijd zou zijn en aan de hier en daar geuite twijfel aan het verdere bestaansrecht van het genre, omdat enerzijds operette, revue en film, anderzijds de absolute muziek veel meer aan de behoeften van de tijd zouden voldoen. Zelf twijfelt zij echter niet aan het voortbestaan van de opera, en stelt dat het er om gaat dat creatieve geesten er een 'zeitgemässe' vorm aan geven, een vorm die 'onze tijd nodig heeft'.

Evenmin als de redactie blijken de componisten aan het bestaansrecht en aan de toekomst van de opera te twijfelen. Maar over de vraag of, en zo ja op welke wijze de moderne tijd het gezicht van de opera zou moeten gaan bepalen, lopen de meningen sterk uiteen. Alban Berg, wiens expressionistische en atonale opera Wozzeck in I925 in de Berlijnse Staatsoper in première was gegaan, is van mening dat de incorporatie in een opera van 'zeitgemässe' middelen als film, revue en jazz er alleen maar voor zorgt dat zo'n werk 'zeitgemäss' is. 'Aber ein wirklicher Fortschritt kann das ja wohl nicht genannt werden; denn eben da sind wir ja angelangt, können also dadurch allein nicht weiterkommen.' Voor de verdere ontwikkeling van de opera zijn er volgens hem andere middelen nodig dan het gebruik van het nieuwste van het nieuwste en van wat op dat moment toevallig 


\section{BLATIER \\ DER \\ STAATSOPER \\ STÄDTISCHE ER N OPER}

INHALT:

\section{„CHRISTOPH KOLUMBUS“}

PAUL CLATDEL: BEMERKUNG ZUR INSZENIERUNG

PACL CLAUDEL: MEIN "CHRISTOPH KOLUMBUS"

DR. JULIUS KAPP: EINFUHRUNG IN DAS WERK

P. ARAYANTINOS: SZENENBILDER UND FIGURINEN

HEINZ STROH: ZUM LEBEX DES CHRISTOPH KOLUMBUS

P. A. MFRBACH: DER DON QUICHOTTE DES OZEANS

MITTEILUNGEN DER STAATSOPER

X. Jahrg. Heft 29

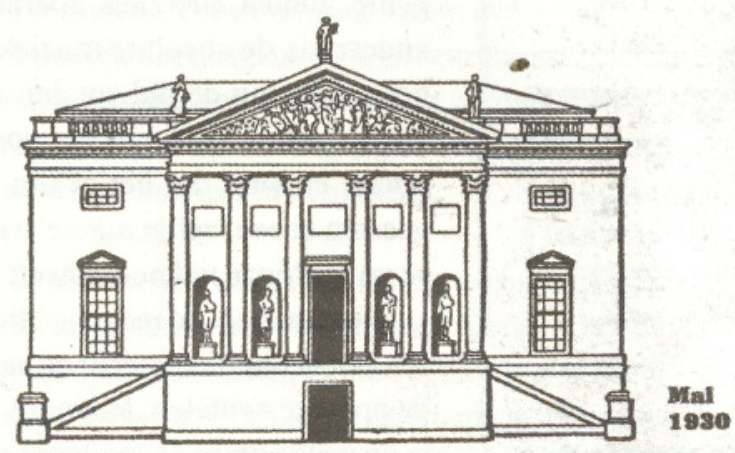

Unverkäufliches Freiexemplar.

Omslag van de Blätter der Staatsoper und der Städtischen Oper in Berlijn

populair is. Anti-modernist Hans Pfitzner neemt een veel radicaler standpunt in. Zijn oordeel luidt kort en krachtig: 'Ich denke, dass eine Weiterentwicklung der Oper unmöglich ist, wenn sie "zeitgemäss" sein soll.' Kurt Weill, even oud als Krenek, laat een heel ander geluid horen. Volgens hem zal de opera een van de belangrijkste factoren zijn in de in alle sectoren van de kunst waar te nemen ontwikkeling, die uiteindelijk zal leiden tot de liquidatie van de society-kunsten. Daarom is deze kunstvorm niet gebaat met enkel esthetische vernieuwingen, noch met de weergave van actualiteiten die alleen maar iets betekenen in de tijd waarin een werk is ontstaan. Wil de opera überhaupt bestaansrecht hebben, dan zal zij zich moeten richten op de interesse- 
gebieden van het brede publiek voor wie zij in de naaste toekomst bestemd zal zijn. De ongecompliceerdheid van stof en uitdrukkingsmiddelen, passend bij de meer naïeve instelling van het nieuwe publiek, leidt tot een episch karakter - Weill spreekt over een 'epische Haltung' - van het muziektheaterwerk. Dit maakt het volgens hem mogelijk om de opera een 'absolut-musikalische, konzertante' vorm te geven, zonder daarbij de wetten van het theater te veronachtzamen. ${ }^{17}$

Weills antwoord op de enquête van de Blätter der Staatsoper und der Städtischen Oper moet gezien worden tegen de achtergrond van zijn samenwerking met Bertolt Brecht. De twee hadden elkaar in het voorjaar van 1927 leren kennen. Hun eerste samenwerkingsproject, het 'Songspiel' Mahagonny, gebaseerd op de 'Mahagonny-Gesänge' uit Brechts dichtbundel Hauspostille, was in de zomer van datzelfde jaar tijdens het muziekfestival in Baden-Baden in première gegaan. Tot 1930 zouden er nog vijf gezamenlijke projecten volgen, met als meest succesvolle de Dreigroschenoper in 1928. Hun samenwerking stond in het teken van een nieuw type muziektheater, dat zij in verschillende poëticale geschriften met het woord 'episch' karakteriseerden. Wat de stellingname van Weill zo interessant maakt, is dat er niet alleen tot uitdrukking komt wat hem en Brecht verbond - kritiek op de geïnstitutionaliseerde elitecultuur en de overtuiging dat de kunstenaar zich op een breed publiek zou moeten richten -, maar ook wat hen uiteindelijk uit elkaar zou drijven, namelijk Weills opvatting over de rol van de muziek in het epische theater. In de beginfase van hun samenwerking waren de opvattingen van beide kunstenaars over de strekking van de term 'episch' redelijk

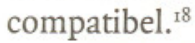

Voor Brecht was 'episch' aanvankelijk synoniem met 'documentair', en had de term betrekking op een vorm van theater die een veel sterker beroep deed op de menselijke rede dan op de emotie. Voor Weill impliceerde het toen nog maar vaag omschreven epische concept een grote mate van muzikale autonomie, met als consequentie een muziekdramatische structuur die gebaseerd was op muzikale principes. Terwijl Brecht zich steeds minder met die visie kon verenigen, bleef Weill aan het primaat van de muziek vasthouden. Dit is weliswaar niet de enige, maar wel een van de belangrijkste oorzaken van het feit dat er in 1930, na de première in Leipzig van het werk waarmee zij drie jaar eerder een begin hadden gemaakt, de opera Aufstieg und Fall der Stadt Mahagonny, een einde kwam aan een unieke samenwerking waaraan het muziektheater in de Republiek van Weimar zo veel vernieuwende impulsen te danken heeft.

-> PAUL OP DE COUL studeerde muziekwetenschap in Utrecht en Berlijn; hij promoveerde met een proefschrift over de opera Doktor Faust (1925) van de Italiaans-Duitse componist Ferruccio Busoni. Sinds 1985 is hij hoogleraar muziekgeschiedenis na 1600 aan de Universiteit Utrecht. 
I Het in januari 2000 gestarte project staat onder auspiciën van het Huizinga Instituut en wordt gefinancierd door NWO en de Deutsche Forschungsgemeinschaft. Als coördinatoren fungeren Thomas Steiert (Bayreuth) en Paul Op de Coul (Utrecht); samen met Jürgen Schläder (München) en Christopher Hailey (Los Angeles) vormen zij een projectgroep die verantwoordelijk is voor de inhoudelijke structurering van het onderzoek.

2 De omvangrijkste mij bekende collectie bevindt zich in de bibliotheek van de Theaterwissenschaftliche Sammlung (Schloss Wahn) van de Universität Köln.

3 Friedrich Michael, 'Deutsche Theaterzeitschriften des letzten Jahrzehnts', in: Literarisches Zentralblatt für Deutschland 75/4, I5. April I924, 30I-315; Carl Diesch, Bibliographie der germanistischen Zeitschriften, Leipzig 1927 (herdruk Stuttgart I970), III-I32,

4 Het voorgaande is gebaseerd op de studie over het theaterprogramma van Heide Kressin, Die Entwicklung des Theaterprogrammheftes in Deutschland von 1894-1941. Ein publizistisches Mittel im Dienst des Theaters (Diss. FU Berlin I968), München I968. In deze dissertatie wordt alleen aandacht besteed aan het huis- of programmatijdschrift voorzover het betrekking heeft op het toneel.

5 De gedachte dat theaters een maatschappelijke functie hebben, leeft sterk in Duitsland sinds de tweede helft van de achttiende eeuw, toen het idee van het het nationale theater terrein begon te winnen.

6 Het Baden-Badener Bühnenblatt verscheen sinds I92I als bijlage van het Badeblatt; de Dramaturgische Blätter van het Nationaltheater in Mannheim waren tussen 1926 en 1928 een wekelijkse bijlage van de Mannheimer Theater- und Verkehrs-Zeitung.

7 Cf. Paul Op de Coul, 'A Viennese Journal for Modern Music: Musikblätter des Anbruch', in: Sophie Levie (ed.), Reviews, Zeitschriften, Revues. Die
Fackel, Die Weltbühne, Musikblätter des Anbruch, Le Disque vert, Mécano, Versty (Avant Garde Critical Studies 9), Amsterdam/Atlanta, GA 1994, 57-95, hier 69.

8 Cf. Kressin, $56 \mathrm{ff}$.

9 Cf. Kressin, 82ff.

Io Erhard Schütz/Jochen Vogt (eds.), Der Scheinwerfer. Ein Forum der neuen Sachlichkeit 1927-1933, Essen 1986, $36 \mathrm{r}$.

II De bibliografische data zijn ondergebracht in een op auteur geordend databestand. Over elke auteur zijn vier groepen van gegevens opgenomen: I) biografische gegevens, 2) geschriften, 3) secundaire literatuur, 4) producties waaraan werd meegewerkt.

I2 Een uitzondering die de regel bevestigt, is de door Marion Linhardt bezorgde editie van de verzamelde geschriften van regisseur Arthur Maria Rabenalt, waarvan inmiddels twee delen zijn verschenen: Schriften zum Musiktheater der $20 \mathrm{er}$ und zoer Jahre, Band I: Opernregie 1, Band 2: Opernregie 2, Hildesheim 1999, 2000.

I3 Niet-Duitstalige werken werden in Duitse (en Oostenrijkse) theaters altijd opgevoerd in Duitse vertaling.

I4 'Kapellmeister und Opernregie. Eine Umfrage', Die Scene 18/5, Mai 1928, 130-154.

I5 Die Scene 18/5, Mai 1928, I42.

I6 'Rundfrage: "Wie denken Sie über die Zeitgemässe Weiterentwicklung der Oper?"', Blätter der Staatsoper und der Städtischen Oper 8/4, Oktober 1927, I2-I9.

I7 De tekst is opgenomen in de nieuwste editie van Weills verzamelde geschriften: Kurt Weill. Musik und musikalisches Theater. Gesammelte Schriften. Mit einer Auswahl von Gesprächen und Interviews, ed. Stephen Hinton/Jürgen Schebera, Mainz 2000, 60 .

I8 Cf. Susan Borwick, 'Weill's and Brecht's theories on music drama', The Journal of Musicological Research 4, 1982, 39-67. 